\title{
FAKTOR PENENTU KEPUASAN DAN MINAT KUNJUNG ULANG EKOWISATA
}

\section{THE DETERMINANTS OF SATISFACTION AND INTENTION TO REVISIT ECOTOURISM}

\author{
Ristya Primadi $^{*}$,, Megawati Simanjuntak $^{* * *}$, dan Istiqlaliyah Muflikhati**) \\ *) Sekolah Bisnis, IPB University \\ Jl. Raya Pajajaran, Bogor 16151 \\ **) Departemen Ilmu Konsumen dan Keluarga, Fakultas Ekologi Manusia, IPB University \\ Jl. Kamper, Kampus IPB Dramaga Bogor 16680
}

\begin{abstract}
Satisfaction becomes an essential factor in knowing how high the tourist interest to make a revisit. The determinants of satisfaction include physical evidence, emotional factors, service quality, and tourist destination components (4A). This research aimed to (1) analyze the impact of physical evidence, emotional factors, service quality, and tourist destination components (4A) on consumer satisfaction and intention to revisit ecotourism and (2) formulate managerial implication obtained for the company to increase tourist visit. The population in this research was Terminal Wisata Grafika Cikole (TWGC) visitors. The sampling method used was convenience sampling with respondent criteria of at least 17 years old and visited TWGC at least once. There were 210 respondents in this research. The data were collected by asking the questionnaire questions through direct interviews with the TWGC visitor, then conducted in-depth interviews with 50 respondents to follow up with the research finding. Based on the research, physical evidence, emotional factors, and service quality positively impacted consumer satisfaction. Meanwhile, tourist destination components (4A) had no significant effect on customer satisfaction. Furthermore, consumer satisfaction had a positive impact on the intention to revisit. In conclusion, the higher consumer satisfaction, the higher the revisit interest.
\end{abstract}

Keywords: components of tourist destinations, customer satisfaction, emotional factors, intention to revisit, physical evidence

\begin{abstract}
Abstrak: Kepuasan menjadi faktor penting dalam mengetahui seberapa tinggi minat wisatawan dalam melakukan kunjungan ulang. Faktor penentu kepuasan diantaranya, physical evidence, emotional factor, service quality dan komponen destinasi wisata (4A). Penelitian bertujuan untuk (1) menganalisis pengaruh physical evidence, emotional factor, service quality dan komponen destinasi wisata (4A) terhadap kepuasan konsumen dan minat kunjung ulang ekowisata dan (2) merumuskan implikasi manajerial yang dapat diterapkan bagi perusahaan dalam meningkatkan kunjungan wisatawan. Populasi dalam penelitian ini adalah pengunjung Terminal Wisata Grafika Cikole (TWGC). Teknik pengambilan sampel menggunakan convenience sampling dengan kriteria responden minimal berusia 17 tahun dan pernah berkunjung ke TWGC minimal satu kali. Responden pada penelitian ini berjumlah 210 responden. Sumber data yang digunakan pada penelitian ini adalah data primer. Teknik pengumpulan data dilakukan dengan wawancara secara langsung kepada pengunjung TWGC terkait dengan pertanyaan yang sudah tertera pada kuesioner, kemudian dilakukan wawancara mendalam kepada 50 responden untuk mempertajam hasil temuan penelitian. Berdasarkan hasil penelitian, physical evidence, emotional factor dan service quality berpengaruh positif signifikan terhadap kepuasan konsumen sedangkan komponen destinasi wisata (4A) tidak berpengaruh signifikan terhadap kepuasan konsumen. Selain itu, kepuasan konsumen berpengaruh positif signifikan terhadap minat kunjung ulang. Artinya, semakin tinggi tingkat kepuasan pengunjung, maka minat kunjung ulang akan semakin meningkat.
\end{abstract}

Kata kunci: komponen destinasi wisata, kepuasan konsumen, emotional factor, minat kunjung ulang, physical evidence

\footnotetext{
${ }^{1}$ Corresponding author:

Email: primadi.rst17@gmail.com
} 


\section{PENDAHULUAN}

Ekowisata merupakan kegiatan pariwisata yang bersifat rekreasi,pendidikandankonservasi.MenurutSastrayuda (2010), manfaat ekowisata diantaranya adalah mendidik wisatawan terkait fungsi dan manfaat lingkungan, alam dan budaya, meningkatkan kesadaran akan lingkungan dan budaya serta mengurangi dampak kegiatan manusia terhadap lingkungan. Pengunjung ekowisata memiliki karakteristik, pola kunjungan serta kebutuhan atau alasan tertentu untuk melakukan kunjungan ekowisata. Hal ini perlu menjadi pertimbangan bagi para penyedia jasa ekowisata, sehingga dalam menyediakan produk ekowisata dapat sesuai dengan minat dan kebutuhan pengunjung (Matondang et al. 2017).

Kepuasan wisatawan mempengaruhi wisatawan dalam memilih destinasi, mengonsumsi produk dan jasa serta keputusan berkunjung kembali. Wisatawan yang puas akan melakukan kunjungan ulang pada waktu yang akan datang dan memberitahukan kepada orang lain atas jasa yang dirasakannya. Menurut Farida et al. (2016), salah satu unsur bauran pemasaran yaitu physical evidence, memiliki arti penting bagi suatu usaha jasa dalam mencapai tujuan perusahaan yaitu kepuasan konsumen. Berdasarkan konsep kepuasan pelanggan yang dikemukakan oleh Irawan (2008), salah satu faktor pendorong kepuasan pelanggan ialah emotional factor. Emotional factor yang dimaksud adalah pelanggan akan merasa puas karena adanya keunggulan emotional value yang diberikan oleh brand dari suatu produk. Kualitas pelayanan merupakan salah satu faktor yang dapat mempengaruhi kepuasan dan minat kunjung ulang ekowisata (Nuraeni, 2014). Kualitas layanan yang baik akan mempengaruhi kepuasan pelanggan. Kebutuhan dan pelayanan daerah tujuan wisata harus didukung dengan empat komponen utama yaitu attraction, accessibility, amenity dan ancillary. Jika komponen tersebut dapat terpenuhi dengan baik, maka kepuasan wisatawan ketika mengunjungi destinasi wisata akan terpenuhi (Suwena dan Wydiatmaja, 2010).

Berdasarkan kondisi persaingan usaha yang semakin ketat, perusahaan penyedia jasa ekowisata perlu memiliki keunggulan untuk mempertahankan bisnisnya. Salah satu cara untuk mempertahankan bisnis adalah dengan mempengaruhi kepuasan dan minat kunjung ulang wisatawan. Kepuasan menjadi faktor penting dalam mengetahui seberapa tinggi minat wisatawan dalam melakukan kunjungan ulang. Wisatawan memiliki standar penilaian tertentu terhadap berbagai hal yang dialami dan dirasakan selama melakukan kunjungan ke destinasi wisata. Hal tersebut merupakan acuan bagi perusahaan untuk menjaga kestabilan bisnisnya ditengah persaingan bisnis. Oleh karena itu, pengetahuan akan persepsi wisatawan terhadap ekowisata penting untuk mengetahui tingkat kepuasan dan minat kunjung ulang wisatawan terhadap destinasi wisata.

Gambar 1 menunjukkan bahwa jumlah pengunjung di TWGC mengalami fluktuasi dari tahun ke tahun. Penurunan signifikan terjadi pada bulan Juni selama 3 tahun terakhir dari tahun 2016-2018. Penurunan jumlah pengunjung TWGC terjadi saat hari dan bulan tertentu saja. Menurut Nugroho dan Sutirman (2016), penurunan jumlah pengunjung ekowisata dapat dipengaruhi oleh beberapa faktor, yaitu fasilitas wisata yang belum memadai dan kualitas pelayanan yang dinilai masih kurang. Selain itu, dapat disebabkan karena objek wisata yang kurang menarik, aksesibilitas yang sulit dijangkau, banyaknya fasilitas yang tersedia tidak terawat dan tidak berfungsi dengan baik, warung makan dan minum yang kurang layak serta keadaan objek wisata yang tidak aman (Novita, 2017). Dalam memasarkan suatu produk/jasa, salah satunya ditentukan oleh perilaku pasca pembelian, dimana konsumen akan mengevaluasi apakah produk/jasa yang dibelinya sudah memberikan kepuasan atau sudah sesuai dengan harapan. Kepuasan konsumen menjadi faktor penting dalam mengetahui seberapa tinggi minat wisatawan dalam melakukan kunjungan ulang.

Tujuan penelitian ini adalah menganalisis pengaruh faktor physical evidence, emotional factor, service quality dan komponen destinasi wisata (4A) terhadap kepuasan konsumen dan minat kunjung ulang ekowisata serta merumuskan implikasi manajerial yang dapat diterapkan bagi perusahaan dalam meningkatkan kunjungan wisatawan.

Penelitian ini mencakup ruang lingkup terbatas pada pengaruh physical evidence, emotional factor dan service quality serta komponen destinasi wisata (4A) yaitu attraction, accessibility, amenity, dan ancillary terhadap kepuasan konsumen dan minat kunjung ulang ekowisata. Wisatawan yang menjadi responden pada penelitian ini dibatasi pada wisatawan yang berusia minimal 17 tahun dan pernah berkunjung ke TWGC minimal satu kali. 


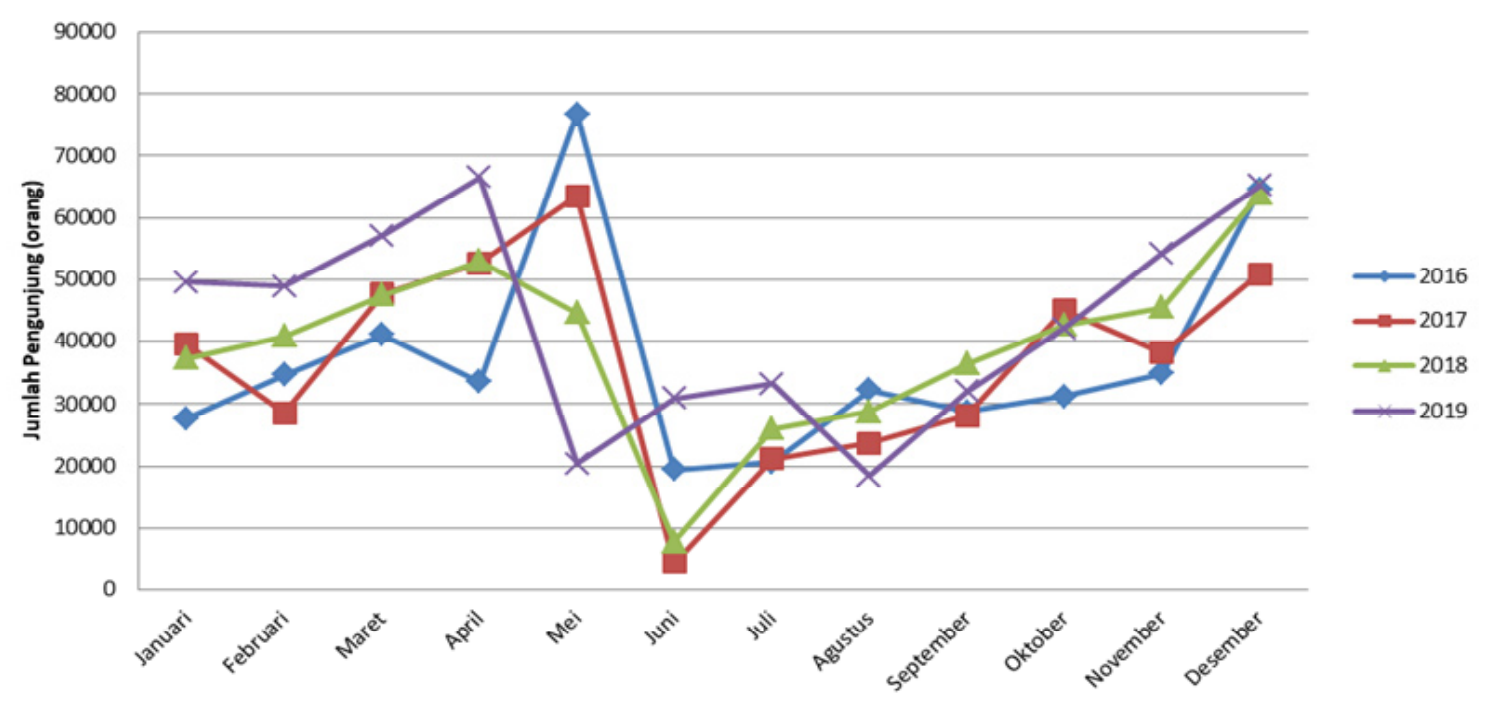

Gambar 1. Tren Pengunjung TWGC

\section{METODE PENELITIAN}

Penelitian ini dilaksanakan di Terminal Wisata Grafika Cikole (TWGC), Lembang, Kabupaten Bandung Barat. Populasi dalam penelitian ini adalah pengunjung objek wisata TWGC. Teknik pengambilan sampel menggunakan convenience sampling yaitu kumpulan informasi dari suatu populasi yang mudah diperoleh serta mampu menyediakan informasi tersebut. Artinya, siapa saja yang dapat memberikan informasi baik secara tidak sengaja atau kebetulan bertemu dengan peneliti, dapat digunakan sebagai sampel jika responden yang memberikan informasi tersebut cocok digunakan sebagai sumber data. Responden yang dipilih adalah pengunjung TWGC yaitu pernah berkunjung minimal satu kali dan berusia minimal 17 tahun. Jumlah responden pada penelitian ini adalah 210 responden.

Sumber data yang digunakan pada penelitian ini adalah data primer. Data primer berupa informasi dari semua variabel independendandependen. Teknikpengumpulan data dilakukan dengan wawancara langsung kepada pengunjung TWGC terkait dengan pertanyaan yang sudah tertera pada kuesioner. Kuesioner dibagi menjadi tiga bagian yaitu screening, profiling dan pertanyaan utama terkait variabel penelitian. Bagian pertama kuesioner dimulai dengan pertanyaan screening untuk mendapatkan responden yang sesuai dengan kriteria pada desain penelitian. Bagian kedua adalah profiling untuk mengetahui profil responden yang meliputi usia, domisili, tingkat pendidikan, jenis pekerjaan serta tingkat pendapatan. Tahap ketiga adalah bagian pertanyaan utama terkait dengan persepsi konsumen mengenai physical evidence, emotional factor, service quality, komponen destinasi wisata (4A), kepuasan konsumen dan minat kunjung ulang ekowisata. Selain itu dilakukan in-depth interview kepada 50 responden untuk mempertajam hasil temuan penelitian.

Penelitian ini terdiri dari 6 variabel laten dan 36 variabel indikator. Variabel dan definisi operasional penelitian mencakup physical evidence, emotional factor, service quality dan komponen destinasi wisata (4A) sebagai variabel independen serta kepuasan konsumen dan minat kunjung ulang sebagai variabel dependen. Terdapat modifikasi pada dimensi variabel service quality, yaitu pada dimensi tangible yang tidak dimasukan kedalam instrumen penelitian karena ada kemiripan dengan dimensi servicescape pada variabel physical evidence. Skala yang akan digunakan adalah skala likert dengan lima tingkat yaitu (1) sangat tidak setuju, (2) tidak setuju, (3) kurang setuju, (4) setuju dan (5) sangat setuju.

Penelitian ini menggunakan analisis kuantitatif dengan pendekatan SEM (Structural Equation Modeling) LISREL (Linear Structural Relationship). Teknik pengolahan dan analisis data pada penelitian ini menggunakan uji validitas, uji realibilitas, analisis deskriptif dan pengujian model dengan SEM LISREL.

Pada Gambar 2 dapat dilihat bahwa pelaksanaan kegiatan penelitian dilakukan untuk menganalisis pengaruh physical evidence, emotional factor, service quality dan komponen destinasi wisata (4A) terhadap kepuasan konsumen dan minat kunjung ulang ekowisata. 


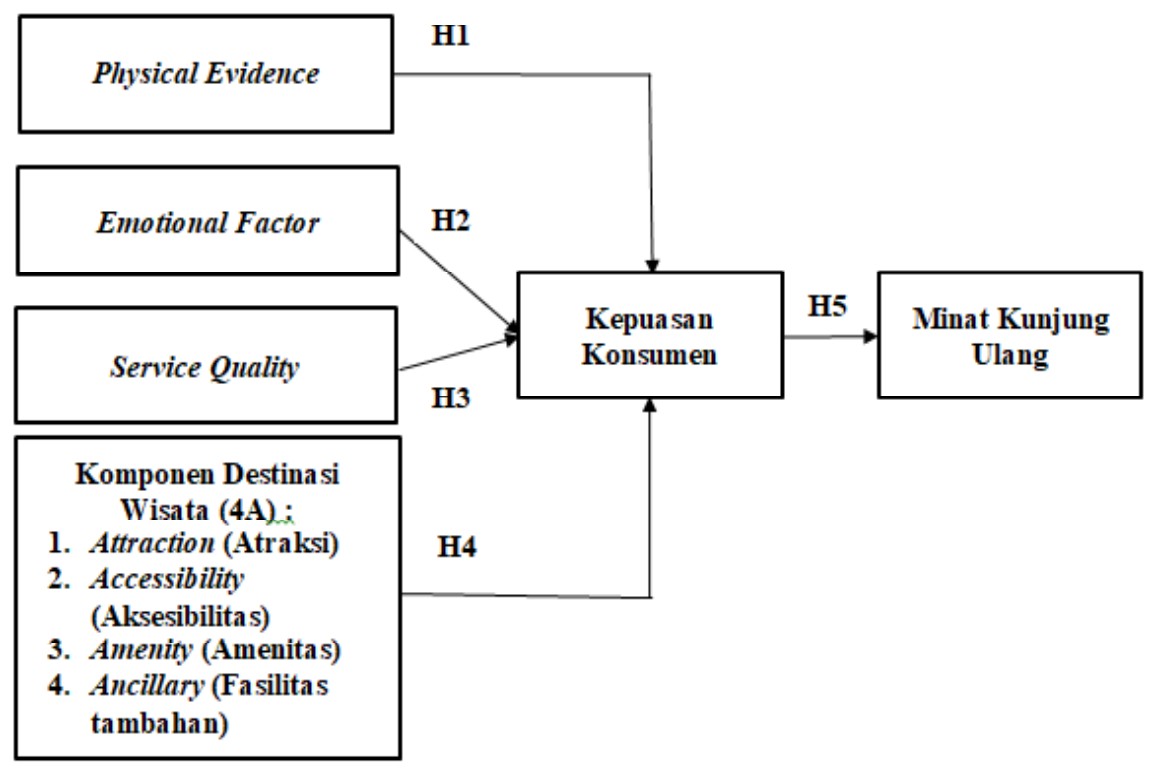

Gambar 2. Kerangka pemikiran penelitian

\section{Hipotesis Penelitian}

H1: Physical evidence berpengaruh positif terhadap kepuasan konsumen

$\mathrm{H} 2$ : Emotional factor berpengaruh positif terhadap kepuasan konsumen

H3: Service quality berpengaruh positif terhadap kepuasan konsumen

H4: Komponen destinasi wisata (4A) berpengaruh positif terhadap kepuasan konsumen

H5: Kepuasan konsumen berpengaruh positif terhadap minat kunjung ulang

\section{HASIL}

\section{Gambaran Umum Terminal Wisata Grafika Cikole (TWGC)}

Terminal Wisata Grafika Cikole berada di bawah Grafika Group yang bergerak dalam bidang restoran, hotel, wisata outbound, catering, percetakan dan education consultant. Grafika Group berawal dari perusahaan percetakan yang dirintis tahun 1969 dengan nama CV Grafika Karya yang beralamat di jalan Kantor Pos No. 2 Gombong, Jawa Tengah. Pada tahun 1982 didirikan Grafika Hotel dan Restoran di kota Gombong, Jawa Tengah. Cabang Grafika Group kemudian berkembang dan tersebar antara pulau Jawa dan Bali.
Terminal Wisata Grafika Cikole dimulai tahun 2006 dengan berdirinya Rest Area Grafika Cikole yang kemudian berkembang menjadi objek wisata Terminal Wisata Grafika Cikole. Terminal Wisata Grafika Cikole berada di atas lahan seluas 9 ha di kaki gunung Tangkuban Perahu dengan ketinggian 1.400 meter di atas permukaan laut, Desa Cikole Kecamatan Lembang, Kabupaten Bandung Barat. Dengan udara sejuk bersuhu $20^{\circ} \mathrm{C}$, dikelilingi hutan pinus dan kontur tanah berbukit menjadikan Terminal Wisata Grafika sebagai lokasi wisata yang tepat untuk menyelenggarakan aktifitas luar ruangan bagi perusahaan, instansi, sekolah maupun sebagai tempat wisata keluarga (Grafika Cikole, 2016).

\section{Karakteristik Responden}

Karakteristik responden digambarkan melalui aspek demografi diantaranya usia, domisili, pendidikan, pekerjaan dan pendapatan. Karakteristik responden bertujuan untuk membantu memahami keragaman jawaban dari responden. Pengunjung wisata tertinggi yaitu berusia 19-29 tahun, berdomisili di Bogor, berada pada jenjang pendidikan sarjana (S1), berprofesi sebagai pegawai swasta serta berpendapatan 6-10 juta. Perbedaan usia pada setiap orang dapat mengakibatkan perbedaan selera dan sikap konsumen. Selain itu, pendapatan dari setiap individu memiliki pengaruh positif dan signifikan terhadap jumlah kunjungan individu (Haban et al. 2017). 


\section{Evaluasi Model SEM}

\section{Hasil Uji Kecocokan Keseluruhan Model}

Berdasarkan hasil analisis, kedua kriteria nilai GFI (Goodness of Fit) dan AGFI (Adjusted Goodness of Fit Index) sudah memperlihatkan kriteria marginal fit, yang berarti ukuran kecocokan model sudah cukup baik dalam menggambarkan data empiris. Menurut Riadi (2013), tingkat kecocokan GFI $\geq 0,9$ adalah good fit, sedangkan bila tingkat kecocokan $0,8 \leq \mathrm{GFI} \leq 0,9$ adalah marginal fit. Hasil goodness of fit selengkapnya ditunjukkan pada Tabel 1.

\section{Hasil Uji Kecocokan Model Struktural}

Nilai standardized loading factor pada model SEM disajikan pada Gambar 3. Kecocokan model struktural berhubungan dengan evaluasi terhadap pengaruh antar variabel laten. Penilaian kecocokan model struktural bertujuan untuk meyakinkan hubungan pada hipotesis yang dibangun berdasarkan teori didukung oleh data empiris yang diperoleh dari penelitian. Kecocokan model struktural dapat dinilai berdasarkan signifikansi koefisienjalur. Pada penelitian ini, tarafsignifikansiyang digunakan adalah 0,05 dengan tingkat kepercayaan 95\%. Dengan demikian signifikansi t-hitung harus berada diatas 1,96. Penilaian model struktural dilakukan pada variabel pengaruh physical evidence, emotional factor, service quality dan komponen destinasi wisata terhadap kepuasan dan minat kunjung ulang. Nilai t-hitung masing-masing jalur H1 sampai $\mathrm{H} 5$ adalah 4,35, 4,23, 4,74, 0,90 dan 7,51. Hal tersebut menunjukkan bahwa hubungan antar variabel laten memiliki hubungan yang signifikan kecuali pada variabel komponen destinasi wisata.

\section{Pengaruh Langsung Variabel Laten}

Pengujian hipotesis penelitian dilakukan dengan menganalisis nilai koefisien jalur dan nilai t-hitung dari model struktural. Pengaruh suatu variabel akan berkesimpulan signifikan apabila nilai koefisien jalur $\geq 0,05$ dengan nilai thitung $\geq 1,96$. Hasil uji hipotesis yang disajikan pada Tabel 2, menunjukkan bahwa variabel yang memiliki pengaruh terbesar terhadap kepuasan konsumen adalah variabel service quality.

\section{Pengaruh Physical Evidence terhadap Kepuasan Konsumen}

Hasil pengujian hipotesis menunjukkan bahwa physical evidence berpengaruh positif signifikan terhadap kepuasan konsumen dengan nilai koefisien jalur 0,37 dan t-hitung 4,35. Hal tersebut sesuai dengan penelitian Manoppo (2013), bahwa pada dimensi dari variabel physical evidence, yaitu servicescape dan otherforms of tangible communication memiliki pengaruh positif terhadap kepuasan konsumen. Hasil tersebut menunjukkan bahwa semakin baik struktur fisik yang ditawarkan oleh suatu perusahaan, maka tingkat kepuasan konsumen akan semakin meningkat. Sarana fisik yang menarik dapat digunakan untuk menjaring pelanggan dari target pasar yang ditentukan (Ananda et al. 2013).

Tabel 1. Hasil uji Goodness-of-Fit

\begin{tabular}{lccc}
\hline Ukuran Goodness-of-Fit & Cut of Value & Hasil & Keterangan \\
\hline RMR (Root Mean Square Residual) & $\leq 0,1$ & 0,052 & good fit \\
RMSEA (Root Mean Square Error of Approximation) & $\leq 0,08$ & 0,059 & good fit \\
GFI (Goodness of Fit) & $\geq 0,9$ & 0,79 & marginal fit \\
AGFI (Adjusted Goodness of Fit Index) & $\geq 0,9$ & 0,76 & marginal fit \\
NFI (Normed Fit Index) & $\geq 0,9$ & 0,96 & good fit \\
CFI (Comparative Fit Index) & $\geq 0,9$ & 0,98 & good fit \\
RFI (Relative Fit Index) & $\geq 0,9$ & 0,95 & goodfit \\
\hline
\end{tabular}

Tabel 2. Hasil uji hipotesis

\begin{tabular}{lcc}
\hline Pengaruh langsung variabel laten & Koef. Jalur & t-hit \\
\hline Physical evidence dan kepuasan konsumen & 0,37 & $4,35^{*}$ \\
Emotional factor dan kepuasan konsumen & 0,28 & $4,23^{*}$ \\
Service quality dan kepuasan konsumen & 0,48 & $4,74^{*}$ \\
Komponen destinasi wisata dan kepuasan konsumen & 0,04 & 0,90 \\
Kepuasan konsumen dan minat kunjung Ulang & 0,75 & $7,51^{*}$ \\
\hline
\end{tabular}




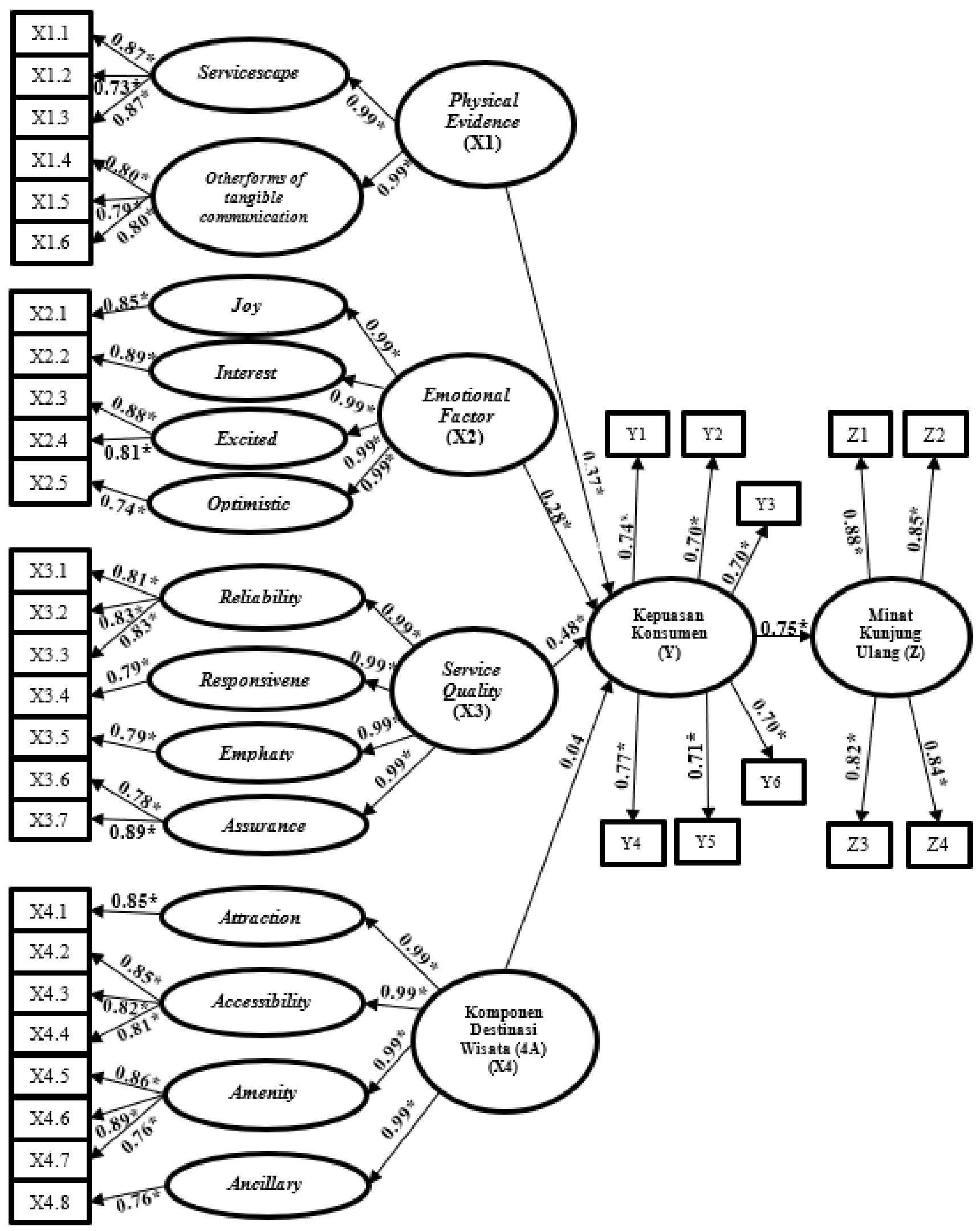

Gambar 3. Nilai standardized loading factor pada model SEM 


\section{Pengaruh Emotional Factor terhadap Kepuasan Konsumen}

Hasil pengujian hipotesis menunjukkan bahwa emotional factor berpengaruh positif signifikan terhadap kepuasan konsumen dengan nilai koefisien jalur 0,28 dan t-hitung 4,23. Hal ini menunjukkan bahwa semakin meningkat rasa emosional yang dirasakan pengunjung terhadap objek wisata, maka tingkat kepuasan konsumen akan semakin tinggi. Hasil tersebut sesuai dengan penelitian Novi (2014), bahwa faktor emosional memiliki pengaruh positif terhadap kepuasan konsumen. Kepuasan emosional pengunjung muncul sebagai perasaan senang dan bahagia ketika mendapatkan fasilitas dan pelayanan yang sesuai dengan yang diharapkan.

\section{Pengaruh Service Quality terhadap Kepuasan Konsumen}

Hasil pengujian hipotesis menunjukkan bahwa service quality berpengaruh positif signifikan terhadap kepuasan konsumen dengan nilai koefisien jalur 0,48 dan t-hitung 4,74. Hasil tersebut sesuai dengan penelitian Sangkaeng et al. (2015), bahwa kualitas pelayanan suatu objek wisata berpengaruh positif terhadap kepuasan wisatawan. Menurut Iskandar et al. (2015), kualitas layanan akan menjadikan konsumen loyal, sehingga perusahaan dapat memahami kebutuhan dan harapan pelanggan serta akan berdampak pada kepuasan konsumen yang merupakan faktor terpenting dalam prioritas pemasaran karena akan menyebabkan konsumen melakukan kunjungan kembali.

\section{Pengaruh Komponen Destinasi Wisata terhadap Kepuasan Konsumen}

Berdasarkan hasil pengujian, menunjukkan bahwa komponen destinasi wisata tidak berpengaruh positif signifikan terhadap kepuasan konsumen. Hasil tersebut tidak sesuai dengan penelitian Wanda dan Pangestuti (2018) yang menunjukkan adanya hubungan positif antara komponen destinasi wisata dan kepuasan pengunjung. Hal serupa juga diteliti Abdulhaji dan Yusuf (2016), yang menunjukkan bahwa dimensi variabel komponen destinasi wisata yaitu attraction, accessibility, ancillary dan amenity memiliki pengaruh positif terhadap kepuasan dan citra destinasi wisata. Hal ini menunjukkan bahwa masih banyak kekurangan terutama pada akses dan fasilitas di TWGC, sehingga pengunjung belum menunjukkan kepuasan terhadap aspek komponen destinasi wisata.

\section{Pengaruh Kepuasan Konsumen terhadap Minat Kunjung Ulang}

Hasil pengujian hipotesis menunjukkan bahwa kepuasan konsumen berpengaruh positif signifikan terhadap minat kunjung ulang. Hal ini menunjukkan bahwa semakin tinggi tingkat kepuasan konsumen maka semakin tinggi pula intensitas kunjungan ulang wisatawan. Hasil serupa dibuktikan oleh Sopyan (2015), yang menunjukkan bahwa variabel kepuasan pengunjung mempunyai pengaruh positif terhadap minat kunjung ulang wisatawan.

Pengelola perlu meningkatkan daya tarik serta kualitas pelayanan untuk mencapai kepuasan pengunjung yang akan berdampak pada niat pengunjung untuk berkunjung ulang di lain waktu. Dengan terciptanya kepuasan wisatawan yang terlahir dari hasil perbandingan antara kenyataan dan harapan, maka akan mendorong wisatawan untuk melakukan kunjungan kembali.

\section{Pengaruh Tidak Langsung Variabel Laten}

Berdasarkan hasil analisis SEM yang ditunjukkan pada Tabel 3, physical evidence memiliki pengaruh positif signifikan terhadap minat kunjung ulang. Hal ini mengindikasikan bahwa physical evidence termasuk kondisi, situasi, suasana, fasilitas yaitu sarana prasarana yang ada di objek wisata sesuai dengan harapan pengunjung, sehingga pengunjung merasa puas dan tertarik untuk berkunjung kembali (Putri et al. 2018). Namun, hasil tersebut tidak sesuai dengan penelitian Makalew et al. (2019), yang menyatakan bahwa physical evidence tidak berpengaruh positif terhadap revisit intention.

Emotional factor memiliki pengaruh positif signifikan terhadap minat kunjung ulang. Hal ini mengindikasikan bahwa terdapat nilai emosional yang positif yang diterima dan dirasakan oleh pengunjung terhadap hal-hal terkait dengan TWGC. Nilai emosional akan mempengaruhi kepuasan konsumen karena berkaitan dengan kemampuan produk menciptakan rasa senang bagi penggunanya. 
Tabel 3. Pengaruh tidak langsung variabel laten

\begin{tabular}{lcc}
\hline \multicolumn{1}{c}{ Pengaruh Tidak Langsung } & Koef. Jalur & t-hit \\
\hline Physical evidence dan minat kunjung ulang & 0,28 & $3,76^{*}$ \\
Emotional factor dan minat kunjung ulang & 0,21 & $3,69^{*}$ \\
Service Quality dan minat kunjung ulang & 0,36 & $4,01^{*}$ \\
Komponen destinasi wisata dan minat kunjung ulang & 0,03 & 0,89 \\
\hline
\end{tabular}

Service quality memiliki pengaruh positif signifikan terhadap minat kunjung ulang. Hal ini mengindikasikan bahwa pengunjung puas akan pelayanan yang ditawarkan TWGC. Kualitas pelayanan merupakan hal utama yang menjadi fokus bagi pengelola wisata guna menciptakan kepuasan pengunjung. Berdasarkan hasil analisis SEM, service quality memiliki pengaruh terbesar terhadap minat kunjung ulang. Layanan yang baik akan mempengaruhi probabilitas kunjungan ulang pelanggan (Seetanah dan Teeroovengadum 2018).

Komponen destinasi wisata tidak berpengaruh positif signifikan terhadap minat kunjung ulang. Hal ini mengindikasikan bahwa masih terdapat kekurangan terutama pada fasilitas pendukung, seperti toko cenderamata dan ketersediaan ATM. Hal tersebut mempengaruhi kepuasan pengunjung dan keinginan pengunjung untuk berkunjung kembali. Hasil tersebut bertentangan dengan penelitian Wanda dan Pangestuti (2018), yang menunjukkan bahwa komponen destinasi wisata berpengaruh positif terhadap minat kunjung ulang. Artinya, semakin baik komponen destinasi wisata (4A) suatu objek wisata, maka akan semakin tinggi tingkat kunjungan ulang wisatawan terhadap objek wisata.

\section{Analisis Tingkat Kepentingan Dan Kinerja}

Strategi peningkatan minat kunjung ulang disusun berdasarkan prioritas perbaikan atribut menggunakan grafik Importance-Performance Analysis (IPA). Metode IPA digunakan untuk mengetahui indikator yang dianggap penting bagi pengunjung dan perlu diperbaiki oleh pengelola Taman Wisata Grafika Cikole. Menurut Wong et al. (2011), dengan menggunakan grafik IPA manajemen dapat menentukan atribut terpenting yang perlu ditingkatkan berdasarkan pengukuran persepsi pelanggan terhadap atribut-atribut pelayanan atau jasa. Gambar 4 menunjukkan analisis kinerja berdasarkan persepsi pengunjung TWGC.
Hasil analisis tingkat kepentingan dan kinerja, urutan atribut yang menjadi prioritas utama (high priority) dalam meningkatkan minat kunjung ulang diantaranya adalah pemandangan yang menarik minat pengunjung (EF2), permainan yang menarik minat pengunjung (EF3), rambu-rambu cukup informatif (PE1), lingkungan yang memadai (PE3) dan perasaan senang pengunjung (EF1). Atribut tersebut merupakan aspek yang dianggap penting bagi wisatawan, namun masih rendah dari sisi kinerja yang dilakukan oleh manajemen TWGC.

Urutan atribut yang masuk dalam kategori maintain diantaranya adalah petugas yang ramah (SQ7), petugas mahir dalam mengoperasikan permainan/wahana (SQ3) dan petugas memberikan arahan dengan baik (SQ2). Artibut tersebut merupakan kekuatan yang perlu dipertahankan oleh manajemen ekowisata. Apabila kekuatan tersebut gagal dipertahankan, maka atribut tersebut menjadi prioritas utama yang perlu dikembangkan.

Urutan atribut yang masuk dalam kategori low priority diantaranya adalah wahana yang menarik minat pengunjung (EF4), ketersediaan pusat informasi (PE6), website/sosial media mudah diakses (PE4), penampilan petugas cukup baik (PE5), kunjungan kembali akan menyenangkan (EF5) dan sarana parkir memadai (PE2). Apabila atribut tersebut gagal dipertahankan, maka pelanggan akan tetap memiliki minat kunjung ulang pada ekowisata sehingga hal ini tidak akan menjadi ancaman bagi manajemen ekowisata.

Urutan atribut yang masuk dalam kategori over diantaranyaadalah petugas melayani dengan baik(SQ1), petugas lebih mendahulukan kepentingan pengunjung (SQ5), respon petugas cukup cepat (SQ4), ketepatan waktu petugas dalam melayani pengunjung (SQ6). Secara umum, atribut tersebut telah memenuhi harapan pelanggan sehingga tidak diperlukan pengembangan berkelanjutan. 


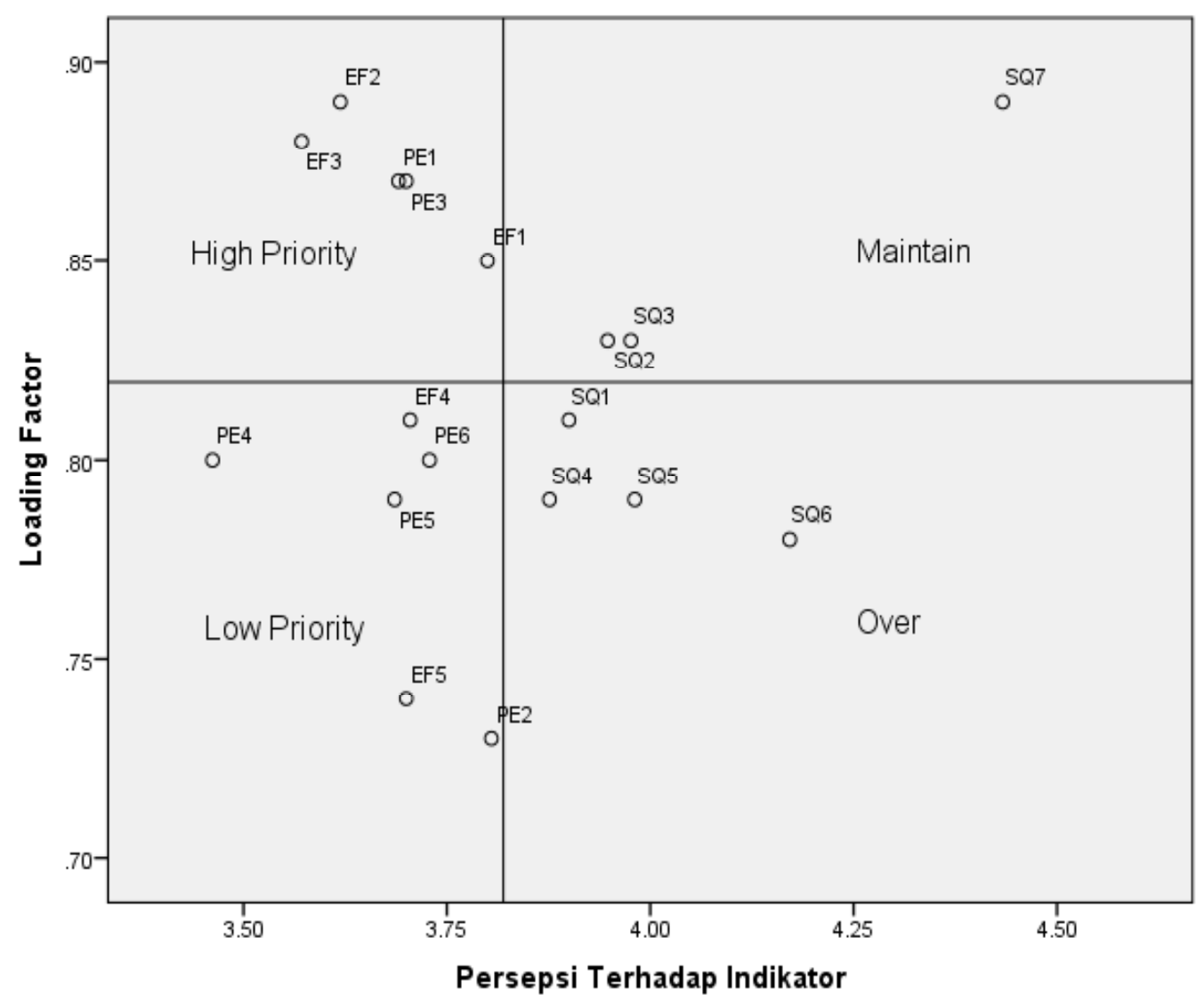

Gambar 4. Analisis kinerja berdasarkan persepsi pengunjung TWGC

Berdasarkan hasil analisis tingkat kepentingan dan kinerja, perbaikan layout dan rambu-rambu wisata, perbaikan dan penambahan permainan baru serta pelaksanaan audit dan evaluasi terkait kualitas pelayanan pegawai dan pengadaan training khusus kepada pegawai menjadi rekomendasi yang dapat dijalankan oleh manajemen wisata dalam meningkatkan minat kunjung ulang wisatawan.

\section{Implikasi Manajerial}

Atribut-atribut kepuasan yang ditunjang melalui hasil analisis SEM, dapat menjadi bahan evaluasi bagi perusahaan. Minat berkunjung ulang dipengaruhi oleh aspek internal dan eksternal. Aspek internal didapat berdasarkan kepuasan seorang pengunjung, sedangkan eksternal didapat berdasarkan lingkungan dan situasi tempat wisata yang dikunjungi pengunjung seperti physical evidence dan komponen destinasi wisata. Salah satu aspek yang perlu diperhatikan adalah lingkungan di TWGC, seperti layout dan kebersihan. Selain itu, perlu evaluasi lebih lanjut terkait dengan promosi baik melalui website maupun media sosial. Emotional factor dapat dijadikan gambaran bagi pengelola untuk mengetahui hal-hal apa saja yang disukai pengunjung. Atribut yang memiliki pengaruh paling besar adalah kepuasan terhadap pelayanan di TWGC. Namun, masih banyak faktor yang harus dibenahi oleh manajemen TWGC untuk meningkatkan kepuasan pengunjung. Kualitas pelayanan di TWGC layak dipertahankan serta segala bentuk pelayanan yang dinilai masih kurang dapat ditingkatkan lagi. Selain itu, aspek fisik seperti sarana parkir masih perlu dievaluasi oleh pengelola serta promosi dibagian sosial media perlu ditingkatkan untuk menarik minat wisatawan. Emotional factor dari pengunjung dapat dijadikan gambaran bagi pengelola untuk mengetahui hal-hal apa saja yang disukai pengunjung sehingga pengunjung senang dan ingin berkunjung kembali.

Dengan peningkatan atribut-atribut kepuasan tersebut diharapkan mampu memberikan kesan yang lebih baik bagi wisatawan sehingga wisatawan puas saat melakukan kunjungan ulang ke TWGC. Kotak saran yang tersedia dapat dimanfaatkan bagi pengunjung untuk menyampaikan aspirasi, baik berupa saran maupun kritik. 


\section{KESIMPULAN DAN SARAN}

\section{Kesimpulan}

Berdasarkan hasil penelitian, physical evidence, emotional factor dan service quality berpengaruh positif signifikan terhadap kepuasan konsumen, sedangkan komponen destinasi wisata (4A) tidak berpengaruh signifikan terhadap kepuasan konsumen. Hal tersebut mengindikasikan bahwa terdapat beberapa fasilitas yang dinilai kurang memberikan kepuasan pada pengunjung. Selain itu, kepuasan konsumen berpengaruh positif signifikan terhadap minat kunjung ulang. Artinya, semakin tinggi tingkat kepuasan pengunjung, maka niat kunjungan ulang akan meningkat. Pengembangan wahana dan permainan, perbaikan layout dan rambu-rambu, pelaksanaan audit dan evaluasi terkait kualitas pelayanan pegawai serta pengadaan training khusus setiap hari kepada pegawai merupakan implikasi manajerial yang dapat diterapkan oleh manajemen TWGC untuk meningkatkan kepuasan dan minat kunjung ulang wisatawan.

\section{Saran}

Saran penelitian selanjutnya adalah penambahan dimensi pada variabel service quality, seperti competence, communication, courtesy, understanding dan access serta penambahan faktor lain pada dimensi servicescape yang lebih spesifik dalam menjelaskan lingkunganfisik, berupa atmosphere, facility, cleanlines, spatial layout, sign symbol dan artifact serta overall percieved servicescape untuk menjelaskan lebih detail pada aspek physical evidence. Penelitian selanjutnya dianjurkan untuk mencari pembanding terhadap objek wisata lain. Selain itu, ketika akan melakukan penelitian disarankan tidak saat musim hujan karena akan mempengaruhi tingkat kunjungan.

\section{DAFTAR PUSTAKA}

Abdulhaji S, Yusuf IS. 2016. Pengaruh Atraksi, Aksesibilitas, Fasilitas terhadap Citra Objek Wisata Danau Tolire Besar di Kota Ternate. Jurnal Penelitian Humano 7(2): 134-148. https:// doi.org/ 10.33387/hjp.v7i2.317.

Ananda RP, Ahman E, Riwanudin O. 2013. Pengaruh Physical Evidence Objek Wisata Pemandian Air Panas Ciwalini terhadap Keputusan Berkunjung Wisatawan. Tourism and Hospitality Essentials
Journal (THE Journal) 3(1): 461-482. https:// doi.org/10.17509/ thej.v3i1.1966.g1349.

Farida I, Tarmizi A, November Y. 2016. Analisis Pengaruh Bauran Pemasaran 7P Terhadap Kepuasan Pelanggan Pengguna Gojek Online. Jurnal Riset Manajemen Dan Bisnis Fakultas Ekonomi UNIAT 1(1): 31-40. https://doi. org/10.36226/jrmb.v1i1.8.

Grafika Cikole. 2016. Profil Terminal Wisata Grafika Cikole. http://grafikacikole.com/ [20 jan 2020].

Haban Y, Koleangan RAM, Kawung GMV. 2017. Analisis Faktor-Faktor yang Mempengaruhi Jumlah Kunjungan dan Nilai Ekonomi Kebun Raya Bogor [tesis]. Manado: Program Pascasarjana, Universitas Sam Ratulangi.

Irawan H. 2008. Manajemen Pemasaran Modern. Yogyakarta: Liberty.

Iskandar D, Nurmalina R, Riani E. 2015. The Effect of Service, Product Quality and Perceived Value on Customer Purchase Intention and Satisfaction. Indonesian Journal of Business and Entrepreneurship (IJBE) 1(2): 51-62. https://doi. org/10.17358/IJBE.1.2.51.

Makalew AJL, Mananeke L, Lintong DCA. 2019. Analisis Faktor-Faktor yang Mempengaruhi Revisit Intention Wisatawan pada Objek Wisata Alam Batu Angus di Bitung. Jurnal Riset Ekonomi, Manajemen, Bisnis dan Akuntansi 7(3): 2631-2640. https://doi.org/ 10.35794/emb a.v7i3.23712.

Manoppo F. 2013. Pengaruh Kualitas Pelayanan dan Servicescape terhadap Kepuasan Konsumen pada Hotel Gran Puri Manado. Jurnal Riset Ekonomi, Manajemen, Bisnis dan Akuntansi 1(4): 1341-1348. https://doi.org/10.35794/emba. v1i4.2913.

Matondang MA, Bahruni, Hermawan R. 2017. Pengaruh Tingkat Kepuasan Pengunjung terhadap Willingness to Pay di Plengkung Taman Nasional Alas Purwo. Jurnal Media Konservasi 22(2): 164-170.

Novi AF. 2014. Pengaruh Service Quality dan Emotional Factor terhadap Kepuasan Pelanggan pada The Laguna A, Luxuary Collection Resort dan Spa Nusa Dua Tahun 2014. Jurnal Fakultas Ekonomi dan Bisnis 4(1): 1-10.

Novita M. 2017. Faktor Penyebab Menurunnya Wisatawan Berkunjung ke Objek Wisata Seminung Lumbok Resort Tahun 2016. Jurnal FKIP Universitas Lampung Hal 1-11.

Nugroho FG, Sutirman. 2016. Faktor-Faktor yang 
Mempengaruhi Jumlah Pengunjung di Objek Wisata Air Bojongsari (Owabong). Jurnal Pendidikan Administrasi Perkantoran 5(4): 366379.

Nuraeni BS. 2014. Analisis Faktor-Faktor yang Mempengaruhi Minat Kunjung Ulang Wisatawan Museum Ranggawarsita Semarang. Jurnal Bisnis Strategi 23(1): 1-20. https://doi.org/10.14710/ jbs.23.1.1-20.

Putri KA, Zainal SL, Setiawan H. 2018. Pengaruh Physical Evidence terhadap Minat Kunjung Kembali Wisatawan ke Museum Negeri Sumatera Selatan. Jurnal Administrasi Bisnis pp. 1-12.

Riadi E. 2013. Aplikasi LISREL untuk Penelitian Analisis Jalur. Yogyakarta: Andi.

Sangkaeng S, Mananeke L, Oroh SG. 2015. Pengaruh Citra, Promosi, Kualitas Pelayanan Objek Wisata terhadap Kepuasan Wisatawan di Objek Wisata Taman Laut Bunaken Sulawesi Utara. Jurnal Ekonomi, Manajemen, Bisnis dan Akuntansi 3(3): 1089-1100. https://doi.org/10.35794/emba. v3i3.10113
Sastrayuda GS. 2010. Pengembangan Kawasan Ekowisata. Bandung: UPI Press.

Seetanah B, Teeroovengadum V, Nunkoo RS. 2018. Destination Satisfaction and $\quad R$ e $v$ i s i t Intention of Tourists: Does the Quality of Airport Services Matter? Journal of Hospitality and Tourism Research 20(10): 1-15. https://doi. org/10.1177/1096348018798446

Sopyan IW. 2015. Anteseden Minat Berkunjung Ulang (Studi pada Cagar Budaya Bedung Lawang Sewu Semarang). Journal of Management 4(2): 1-9.

Suwena IK, Widyatmaja IG. 2010. Pengetahuan Dasar Ilmu Pariwisata. Denpasar: Universitas Udayana.

Wanda IBK, Pangestuti E. 2018. Pengaruh Pengembangan Komponen Destinasi Wisata terhadap Kepuasan Pengunjung. Jurnal Administrasi Bisnis 55(3): 1-9.

Wong M, Hideki N, George P. 2011. The use importanceperformance analysis (IPA) in evaluating Japan's e-goverment services. Journal of Theoretical and Applied Electronic Commerce Research 6(2): 17-30. https://doi.org/10.4067/S071818762011000200003 . 